\title{
Huge solitary osteochondroma at T11 level causing myelopathy: case report
}

\author{
Koichiro Okuyama ${ }^{1}$, Mitsuho Chiba ${ }^{1}$, Kyoji Okada ${ }^{2}$, Kozo Sato ${ }^{2}$ and Naoto Hoshi ${ }^{3}$ \\ ${ }^{1}$ Department of Orthopaedic Surgery, Akita Rosai Hospital; ${ }^{2}$ Department of Orthopaedic Surgery, Akita University \\ School of Medicine and ${ }^{3}$ Second Department of Pathology, Akita University School of Medicine, Japan
}

\begin{abstract}
A solitary osteochondroma of the vertebral column is rare, and also it will rarely cause neurological deficits. Myelopathy from a tumour usually presents insidiously with neurological deficits. We report a case of a huge solitary osteochondroma at T11 level with an acute onset of myelopathy induced by a minor trauma.

MRI findings of a spinal osteochondroma has rarely been described. In our patient, the MRI demonstrated an outer osteochondral layer and an ossified centre of the mass. A literature review has also been undertaken.
\end{abstract}

Keywords: huge solitary osteochondroma; thoracic spine; myelopathy; acute onset; magnetic resonance image (MRI)

\section{Case report}

A 60-year-old man was admitted to the Akita Rosai Hospital in December 1992, with a chief complaint of slowly increasing weakness and numbness of both lower extremities, more right than left, for 5 years. He reported that the illness began immediately after falling onto his buttock from a horizontal bar.

On examination, there was no tenderness over his back, and the general physical examinations were normal, without any obvious exostoses in the trunk or extremities. The dorsiflexors and evertors of the right foot were very weak $(2 / 5)$ in the right foot, and the score was 4 in the left foot. There was sensory loss below the T12 dermatome on the right side and below the L4 dermatome on the left side. The right patellar tendon reflex was depressed, Babinski reflexes were present, as was ankle clonus. There was a neuropathic bladder, being hyperactive. The residual urine volume was $70 \mathrm{ml}$.

Plain roentgenograms demonstrated an abnormal ossified mass, protruding into the spinal canal, medial to the left T11/T12 facet joint. A myelogram showed the spinal cord to be severely compressed by an extradural ossified mass from the dorsal aspect (Figure 1). Computer assisted tomograms (CT) with and without contrast medium revealed an elliptically ossified mass, arising from the left inferior articular process of $\mathrm{T} 11$, was projecting into the spinal canal beyond the mid-line, and the spinal cord was severely flattened by the lesion (Figure 2).

A T1-weighted sagittal view of MRI (TR: $440 \mathrm{~ms}$ and TE: $25 \mathrm{~ms}$, spin-echo) demonstrated an elliptical mass of high signal intensity covered with a low-signal

Correspondence: K Okuyama curvilinear line (Figure 3a). The mass showed mixed signal intensity with a low-signal curvilinear line on a T2-weighted image (TR: $3000 \mathrm{~ms}$ and TE: $100 \mathrm{~ms}$, fast spin-echo) (Figure 3b).

In January 1993, a wide laminectomy from T10 to T12 was performed with excision of a $1.5 \times 2 \times 3 \mathrm{~cm}$ cartilaginous mass, which was projecting into the spinal canal beyond the mid-line, with a bony connection with the left inferior articular process of T11. The spinal cord was severely compressed from the left to the right. Although the cartilaginous surface was smooth, it was severely adherent to the duramater, therefore complete gross resection of the mass required partial excision of the dura. The duramater defect was closed with fascia and fibrin sealant. Postoperatively, there was moderate decrease of the sensory change in the legs, but with no recovery of muscle lower strength. The neuropathic bladder improved, and the residual urine volume has decreased to $20 \mathrm{ml}$.

Microscopic examination of the tumour showed that part of it consisted of irregular bony trabeculae and fatty bone marrow. The surface of the lesion was covered with a thin layer of cartilage. The high power view demonstrated that cartilaginous cells in the surface area of the lesion were irregularly distributed. The pathological diagnosis was osteochondroma (Figure 4a,b).

\section{Discussion}

Osteochondromas in the spine have been rarely reported. Albrecht ${ }^{1}$ reported the incidence to be $3.0 \%$ of all osteochondromas. In Dahlin's data, ${ }^{2}$ the incidence was 3.3\%. Furthermore, spinal cord compression causing neurological deficits is very unusual. 
The author reviewed 22 cases of osteochondroma of the thoracic spine with myelopathy (Table 1 for

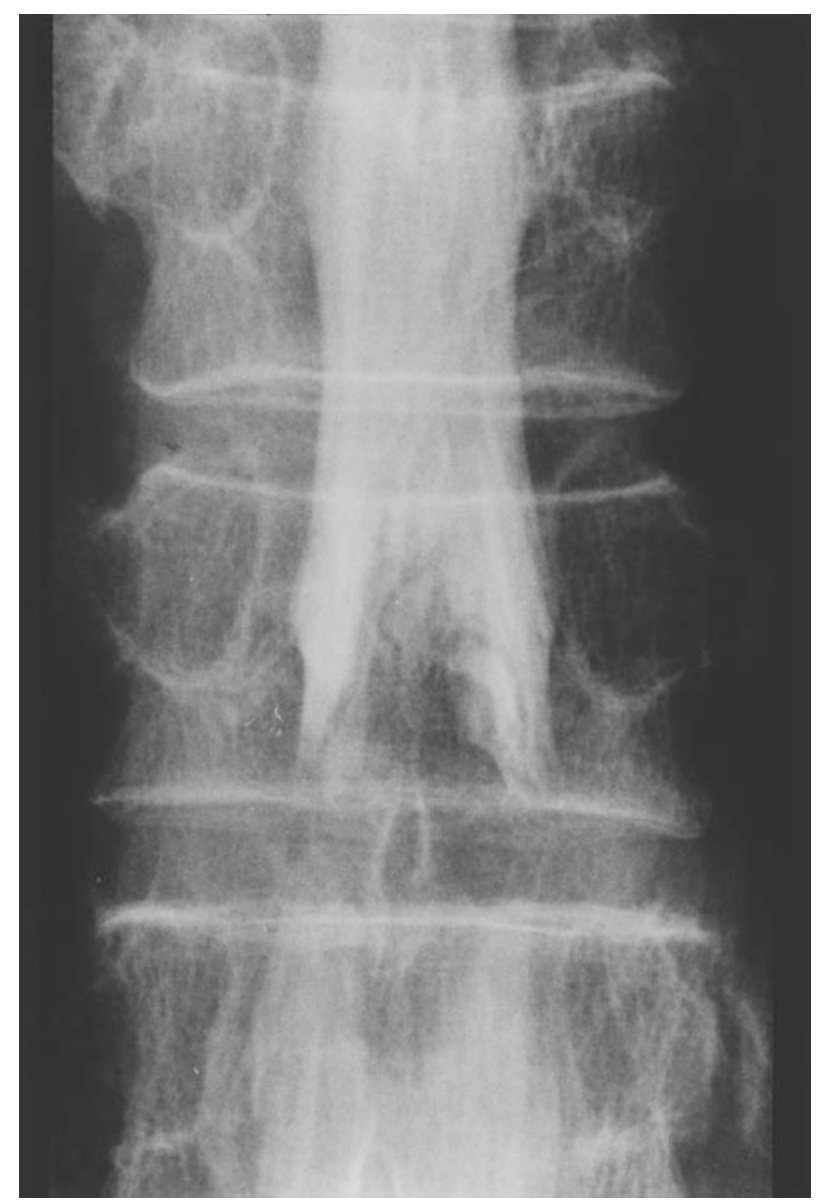

Figure 1 Myelogram showing the spinal cord severely compressed by an extradural ossifying mass from the dorsal aspect

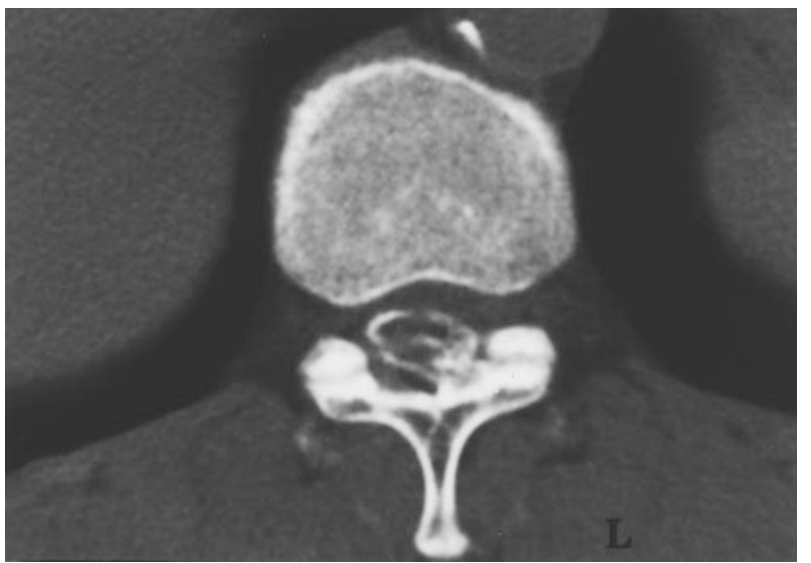

Figure 2 Computerized tomogram demonstrating an elliptically ossified lesion at the left inferior articular process of $\mathrm{T} 11$, and the spinal cord severely flattened by the lesion solitary,,$^{3-13}$ and Table 2 for hereditary ${ }^{14-22}$ ). Solitary osteochondromas have been reported in 12 cases (male eight, female four) with an average age of 30 years (ranging from 12 to 61 years), and with an average symptom duration of 12 months (ranging from 1 to 60 months). Hereditary multiple exostoses have also been reported in ten cases (male seven, female three) with an average age of 26 years (ranging from 9 to 58 years), and with an average symptom duration of 51 months (ranging from 1.5 to 384 months). The T4 vertebra is the most commonly affected level for a solitary osteochondroma $(42 \%)$. The T11 vertebra is rarely uninvolved; the patients of Lanzieri ${ }^{10}$ and Cannon ${ }^{14}$ were reported although the tumour involved the adjacent vertebrae. The size of the osteochondroma that we are reporting was very large, and flattened the spinal cord. No similar case was found in the literature. The original site of the

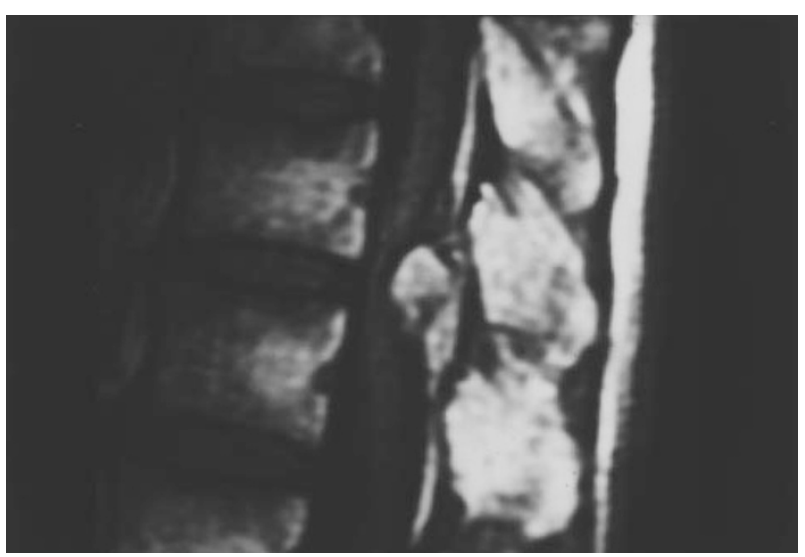

a

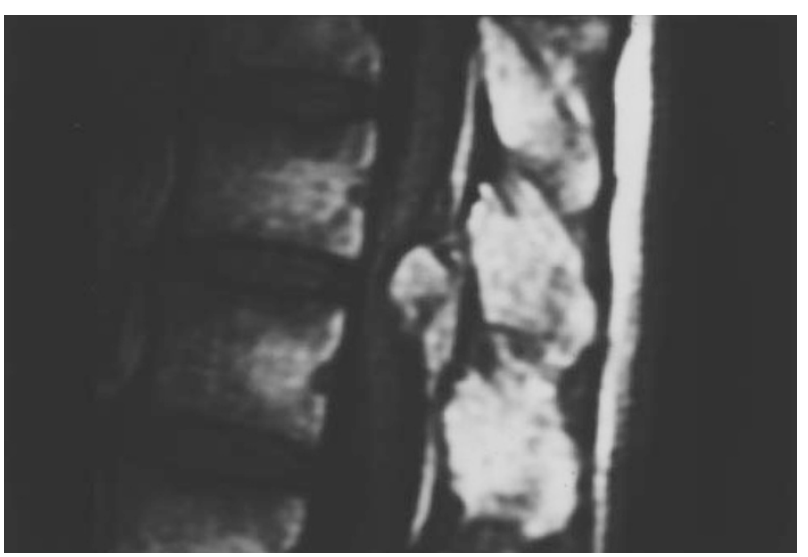

Figure 3 A T1-weighted sagittal view of MRI (TR: $440 \mathrm{~ms}$ and TE: $25 \mathrm{~ms}$ ) demonstrating an elliptical mass with high signal intensity surrounded a low-signal curvilinear line (a). A T2-weighted image (TR: $3000 \mathrm{~ms}$ and TE: $100 \mathrm{~ms}$ ) showing a mass of mixed intensity also surrounded by a low-signal curvilinear line (b) 
lesion has been described in nineteen cases. The costovertebral junction including the rib head being the most common origin, $42 \%$ of the solitary osteochondroma, and $40 \%$ of hereditary multiple exostoses, respectively. The intervertebral joint, facet and pedicle were also noted to be affected.

Our patient developed an immediate neurological deficit after a fall on his buttock. Myelopathy from an

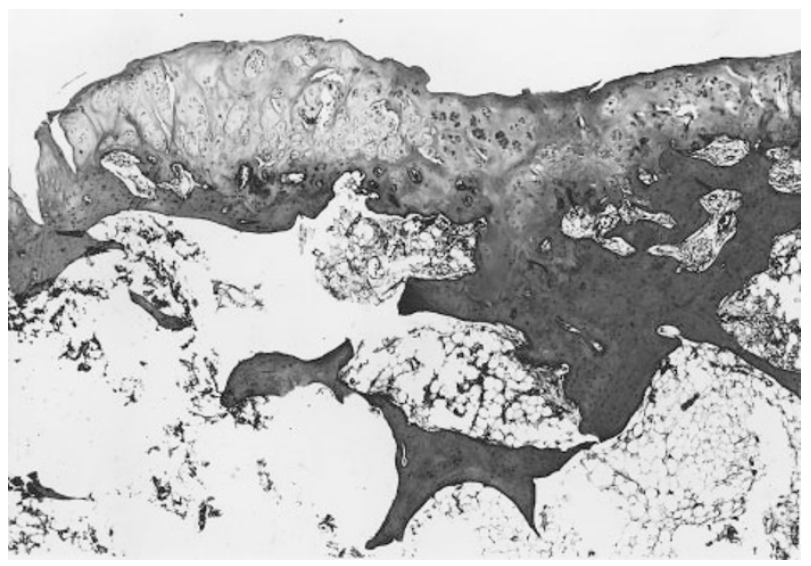

b

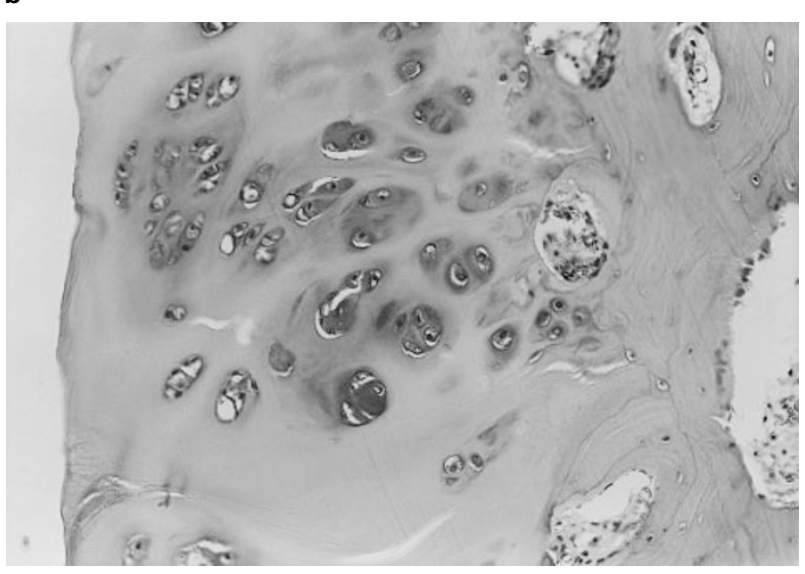

Figure 4 Photomicrograph (a) revealing the lesion consisted of an irregular bony trabeculae with a fatty bone marrow, and a thin layer of the cartilage covering the surface of the lesion. High power view demonstrating cartilaginous cells in the surface of the lesion irregularly distributed, and mild nuclear atipia. a: original magnitude $\times 7.5 \mathbf{b}$ : original magnitude $\times 50 \mathrm{H} \& \mathrm{E}$

Table 1 Summary of 12 cases of thoracic myelopathy resulting from a solitary osteochondroma

\begin{tabular}{|c|c|c|c|c|c|c|c|}
\hline $\begin{array}{l}\text { Authors } \\
\text { (ref no.) }\end{array}$ & Year & Age & Sex & $\begin{array}{l}\text { Affected } \\
\text { level }(s)\end{array}$ & Origin & $\begin{array}{c}\text { Duration of } \\
\text { neurological } \\
\text { Symptoms }\end{array}$ & $\begin{array}{c}\text { Surgical } \\
\text { Result }\end{array}$ \\
\hline \multirow[t]{2}{*}{ Bradford FK (3) } & 1954 & 29 & Male & $\mathrm{T} 8$ & Vertebral body & 3 months & Not improved \\
\hline & & 61 & Male & T9 & Vertebral body & 1 year & Not improved \\
\hline Twersky J (4) & 1975 & 12 & Male & $\mathrm{T} 4-7$ & Rib posterior portion & 1 month & Excellent \\
\hline Natarajan M (5) & 1976 & 21 & Male & $\mathrm{T} 4-5$ & Costovertebral angle & 2 months & Good \\
\hline Loftus CM (6) & 1980 & 28 & Male & $\mathrm{T} 4$ & Pars interarticularis & 5 years & Good \\
\hline Spallone A (7) & 1981 & 22 & Female & $\mathrm{T} 1-2$ & Intervertebral joint/Pedicle & 2 years & $?$ \\
\hline Karian (8) & 1984 & 24 & Male & $\mathrm{T} 4$ & Pedicle/Vertebral body & 3 months & Improved \\
\hline Kak VK (9) & 1985 & 40 & Female & T6-8 & Pedicle & 7 months & \\
\hline Lanzieri CF (10) & 1985 & 18 & Female & T11-12 & Costovertebral junction & & \\
\hline Linkowski (11) & 1985 & 33 & Male & T3 & Superior facet/Lamina & 10 weeks & Good \\
\hline Marchand (12) & 1986 & 49 & Female & $\mathrm{T} 8$ & Vertebral body & 1 month & Good \\
\hline Yablon JS (13) & 1990 & 26 & Male & $\mathrm{T} 4$ & Costovertebral junction & & \\
\hline our patient & 1996 & 60 & male & $T 11$ & Inferior articular process & 5 years & Not improved \\
\hline
\end{tabular}

Table 2 Summary of ten cases of thoracic myelopathy due to hereditary multiple exostoses

\begin{tabular}{|c|c|c|c|c|c|c|c|}
\hline $\begin{array}{l}\text { Authors } \\
\text { (ref no.) }\end{array}$ & Year & Age & Sex & $\begin{array}{l}\text { Affected } \\
\text { level }(s)\end{array}$ & Origin & $\begin{array}{c}\text { Duration of } \\
\text { neurological } \\
\text { Symptoms }\end{array}$ & $\begin{array}{c}\text { Surgical } \\
\text { Result }\end{array}$ \\
\hline Cannon JF (14) & 1954 & 23 & Female & $\mathrm{T} 10-12$ & $?$ & 1 year & Good \\
\hline Larson NE (15) & 1957 & 33 & Male & T3 & Costovertebral junction & 18 months & Good \\
\hline Goldenberg DB (16) & 1968 & 23 & Male & T5-6 & Costovertebral junction & 6 weeks & Fair \\
\hline \multirow[t]{2}{*}{ Crowell RM (17) } & 1972 & 13 & Male & $\mathrm{T} 2$ & $?$ & 3 months & Good \\
\hline & & 18 & Male & $\mathrm{T} 8$ & Pedicle? & 4 months & Improved \\
\hline Becker MH (18) & 1978 & 17 & Male & Upper $\mathrm{T}$ & Costovertebral junction & 3 months & Good \\
\hline Ho Su (19) & 1979 & 58 & Female & $\mathrm{T} 1-2$ & Inferoposterior aspect? & 32 years & Not improved \\
\hline Palmer FJ (20) & 1980 & 31 & Female & $\mathrm{T} 2-3$ & Pedicle & 2 years & Improved \\
\hline Buur T (21) & 1983 & 33 & Male & $\mathrm{T} 4$ & $?$ & 6 months & Improved \\
\hline Morikawa F (22) & 1990 & 9 & Male & C7-T1 & Pedicle/Vertebral body & $?$ & Improved \\
\hline
\end{tabular}


osteochondroma usually appears gradually. Myelopathy associated with trauma or a strenuous activity have very rarely been reported. ${ }^{12,23-25}$ The only example in the thoracic spine was reported by Marchand et al. ${ }^{12}$ in 1986 . The rarity of an acute onset of thoracic myelopathy from an osteochondroma may be partly attributed to the limited mobility of the thoracic spine compared to the cervical and lumbar regions. ${ }^{26}$

The MRI appearance of spinal osteochondromas has not often been described. ${ }^{22,27-29}$ In our patient there was a peripheral low rim signal on the T1 and T2-weighted images, which was compatible with an endochrondral ossifying layer, and a high signal on the T1-weighted, a mixed signal on the T2-weighted image in a central area pathologically corresponding to the irregular bony trabeculae with the fatty bone marrow. The perichondrium described by Lee et al. ${ }^{30}$ was not seen. Complete resection of the cartilaginous cap is essential to prevent tumour recurrence, thus, an accurate assessment of the endochondral ossifying or cartilaginous layer of the osteochondroma adjacent to the dura is a preoperative keypoint. In our patient, the MRI showed the benefit of detecting the layer which could not be demonstrated by CT imaging or by the myelogram.

\section{References}

1 Albrecht S, Crutchfield JS, SeGall GK. On spinal osteochondromas. J Neurosurg 1992; 77: 247-252.

2 Dahlin DC. Bone Tumors. 2nd ed, Thomas, 1967; 18-32.

3 Bradford FK. Intraspinal tumors. Dis Nerv Syst 1954; 15: 55-60.

4 Twersky J, Kassner EG, Tenner MS, Camera A. Vertebral and costal osteochondromas causing spinal cord compression. AJR 1975; 124: $124-128$.

5 Natarajan M, Balakrishnan D, Srinivasan V. Solitary osteochondroma causing spinal cord compression. International Surgery 1976; 61: $494-495$.

6 Loftus CM, Rozario RA, Prager R, Scott RM. Solitary osteochondroma of T4 with thoracic cord compression. Surg Neurol 1980; 13: 355-357.

7 Spallone A, di Lorenzo N, Nardi P, Nolletti A. Spinal osteochondroma diagnosed by computed tomography. Report of two cases and review of literature. Acta Neurochirurgica 1981; 58: $105-114$

8 Karian JM et al. Vertebral osteochondroma causing spinal cord compression: Case report. Neurosurgery 1984; 14: $483-484$.
9 Kak VK, Prabhakar S, Khosla VK, Banerjee AK. Solitary osteochondroma of spinal cord compression. Clin Neurol Neurosurg 1985; 87: 135-138.

10 Lanzieri CF, Solodnik P, Sacher M, Hermann G. Computed tomography of solitary spinal osteochondromas. J Compu Assist Tomogr 1985; 9: 1042 - 1044 .

11 Linkowski GD et al. Solitary osteochondroma with spinal cord compression. Surg Neurol 1985; 23: $388-390$.

12 Marchand EP et al. Solitary osteochondroma of the thoracic spine presenting as spinal cord compression. Spine 1986; 11: $1033-1035$.

13 Yablon JS. Osteochondroma of the vertebral column. Neurosurgery 1990; 27: 659-660.

14 Cannon JF. Hereditary multiple exostoses. Am J Hum Genet 1954; 6: $419-425$.

15 Larson NE, Dodge HW, Rushton JG, Dahlin DC. Hereditary multiple exostoses with compression of the spinal cord. Proc Staff Meet Mayo Clinic 1957; 32: 728 - 734.

16 Goldenberg DB, Rienhoff WF, Rao PS. Osteochondroma with spinal cord compression: Report of a case. $J$ de L'association Canadienne Des Radiologistes 1968; 19: 192-194.

17 Crowell RM, Wepsic JG. Thoracic cord compression due to chondrosarcoma in two cousins with hereditary multiple exostoses. J Neurosurg 1972; 36: 86-89.

18 Becker MH, Epstein F. Case report 77. Skeletal Radiol 1978; 3: $197-199$.

19 Ho SU, Lipton HL. Hereditary multiple exostoses with myelopathy. Arch Neurol 1979; 36: 714.

20 Palmer FJ, Blum PW. Osteochondroma with spinal cord compression. Report of three cases. J Neurosurg 1980; 52: $824-845$.

21 Buur T. Hereditary multiple exostoses with spinal cord compression. J Neurol Neurosurg Psychiatr 1983; 46: 96-98.

22 Moriwaka F et al. Myelopathy due to osteochondroma: MR and CT studies. J Comput Assist Tomogr 1990; 14: 128-130.

23 MacGee EE. Osteochondroma of the cervical spine: A cause of transient quadriplegia. Neurosurgery 1979; 4: 259-260.

24 Wen DY, Bergman TA, Haines SJ. Acute cervical myelopathy from hereditary multiple exostoses: Case report. Neurosurgery 1989; 25: $472-475$.

25 Prasad A et al. Solitary spinal osteochondroma causing neural syndromes. Paraplegia 1992; 30: 678-680.

26 White AA, Panjabi MM. Clinical biomechanics of the spine. Philadelphia, JB Lippincott Company; 1990: pp 97-112.

27 Fanney D, Tehranzadeh J, Quencer RM, Nadji M. Case report 415. Skeletal Radiol 1987; 16: $170-174$.

28 Tully RJ, Pickens J, Oro J, Levine C. Hereditary multiple exostoses and cervical cord compression: CT and MR studies. $J$ Comput Assist Tomogr 1989; 13: $330-333$.

29 Jackson A et al. A case of osteochondroma of the cervical spine. Skeletal Radio 1995; 24: 235 - 237.

30 Lee JK, Yao L, Wirth CR. MR imaging of solitary osteochondromas: Report of eight cases. AJR 1987; 149: 557-560. 